\title{
Pseudorotaxane-coupled Gel: A New Concept of Interlocked Gel Synthesis by Using Metathesis Reaction
}

\author{
By Kazuhiro YAmabUKI, Yukio ISOBE, Kenjiro ONIMURA, and Tsutomu OISHI*
}

A unique interlocked gel consisting of an ammonium salt axle having two terminal olefins and a crown ether having two terminal olefins was synthesized by metathesis reaction of pseudorotaxane. The resulting compound showed a swelling in various solvents and showed no solubility.

KEY WORDS: Metathesis Reaction / Pseudorotaxane / Interlocked Compound / Gel / Crown Ether / Ammonium Salt /

Gels are very useful in medical materials and electronic devises. In generally, these gels were categorized as physical gel or chemical gel. However, in recent years, a new type of gel, which is called 'slide-ring gel' or 'topological gel,' has been reported. The new gel was constructed from rotaxane (Figure 1). ${ }^{1-11}$

For example, a gel consisting of cyclodextrin-dimers and poly (ethylene glycol) was reported by Ito et al. ${ }^{12}$ In addition, Takata et al. reported a topologically networked polymer consisting of bisammonium salt axles and poly(crown ether) by using the thiol-catalayzed reversible cleavage of a disulfide linkage, ${ }^{13}$ the former is a hydrogel and the later is an organogel. These polymers consisting of rotaxane structure have come under the spotlight as a third type of gel with a high extensibility, swelling, rebound, and impact absorption properties because movable crosslinks were constructed by inclusion effect.

We also have been researching the synthesis of topological gel by metathesis reaction. Metathesis reaction is a very useful tool for syntheses of various olefin compounds, and also has been used for syntheses of rotaxanes ${ }^{14-17}$ and catenanes. ${ }^{18-20}$ However, a synthesis of rotaxane gel by metathesis reaction has not ever been reported. Moreover, above-mentioned rotaxanes and rotaxane gels must introduce a bulky substituent as a third component into these systems to hold wheel components in axle components. If these stable rotaxane gels are synthesized from two components (a linear axle and a wheel), these synthetic procedures will be simpler. In fact, Gibson et al. reported on rotaxane gels consisting of a liner component and a circle component. ${ }^{21-24}$

In this paper, we propose a new strategy of the simple synthesis of rotaxane gel by using the inclusion reaction between ammonium salt compound and crown ether and by the metathesis reaction between the resulting pseudorotaxaenes which have four double bonds. The important point in our concept is to provide two roles for crown ethers: provision of inclusion sites as a host molecule and prevention of release of themselves as a stopper (Figure 2).

\section{EXPERIMENT}

\section{General}

${ }^{1} \mathrm{H}$ NMR spectra were recorded on JEOL JNM-GX270. Molecular weight and molecular weight distribution were estimated by gel permeation chromatography (GPC) on a shimadzu SPD-10A equipped with an UV detector $(257 \mathrm{~nm})$ and a shimadzu HSG-40, HSG-20, HSG-15, HSG-10 column (i.d., $7.9 \mathrm{~mm}$; length, $30 \mathrm{~cm}$; gel particle size $10 \mu \mathrm{m}$; theoretical plate numbers, $>10,000)$. THF was used as an eluent at a flow rate of $1.2 \mathrm{~mL} / \mathrm{min}$. The molecular weights were calibrated with polystyrene standards. MALDI-TOF mass measurements were performed with Voyager TM DE PRO Y instrument. Elemental analyst was done with a Perkin Elmer 2400 CHNS.

\section{Synthesis of AXLE}

$t$-Butyl $N, N$-Bis(2-hydoxyethyl)carbamate (1). To a solution of diethanolamine $(15.0 \mathrm{~g}, 0.014 \mathrm{~mol})$ and 4-(dimethylamino)pyridine (DMAP) $(0.175 \mathrm{~g}, 1.43 \mathrm{mmol})$ in $\mathrm{CHCl}_{3}(250 \mathrm{~mL})$ was added di-t-butyl dicarbonate $(31.2 \mathrm{~g}, 0.014 \mathrm{~mol})$ and stirred at room temperature for $3 \mathrm{~h}$. Solvent was removed by evaporation. The resulting residue was purified by $\mathrm{SiO}_{2}$ column chromatography (EtOAc/MeOH (10:1)) to give $1(28.1 \mathrm{~g}, 96 \%) .{ }^{25}$

${ }^{1} \mathrm{H}$ NMR $\left(270 \mathrm{MHz}, \mathrm{CDCl}_{3}\right) \delta 3.84-3.72(\mathrm{~s}, 4 \mathrm{H}, \mathrm{HO}-$ $\mathrm{CH}_{2}$ ), $3.45-3.33$ (s, 4H, $\left.-\mathrm{CH}_{2}-\mathrm{N}-\right)$, 1.48-1.42 (s, 9H, -COO$\left.\mathrm{C}\left(\mathrm{CH}_{3}\right)_{3}\right)$.

$t$-Butyl $N, N$-Bis(2-undec-10-enoyloxyethyl)carbamate (2). A solution of $1(14.9 \mathrm{~g}, 0.0723 \mathrm{~mol})$ and triethylamine $(50 \mathrm{~mL}$, $0.362 \mathrm{~mol})$ in THF $(50 \mathrm{~mL})$ was cooled at $0{ }^{\circ} \mathrm{C}$. A solution of 10 -undecenoyl chloride $(44.0 \mathrm{~g}, 0.217 \mathrm{~mol})$ in THF $(50 \mathrm{~mL})$ was added to the mixture, followed by stirring for $10 \mathrm{~min}$. And then, the solution was stirred at room temperature for $86 \mathrm{~h}$. Saturated $\mathrm{NaHCO}_{3}$ was then poured in the solution, followed by extraction with EtOAc. The organic layer was washed with saturated $\mathrm{NaCl}$. The organic layer was dried over anhydrous $\mathrm{MgSO}_{4}$ and evaporated under reduced pressure to give a residue as colorless oil. The residue was purified by $\mathrm{SiO}_{2}$ 

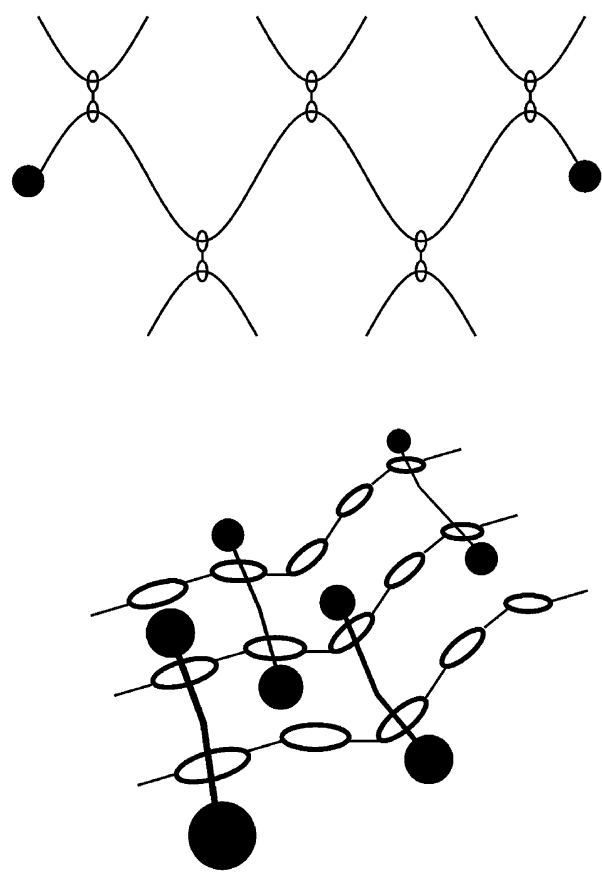

Figure 1. Structures of existing topological polyrotaxane gels.

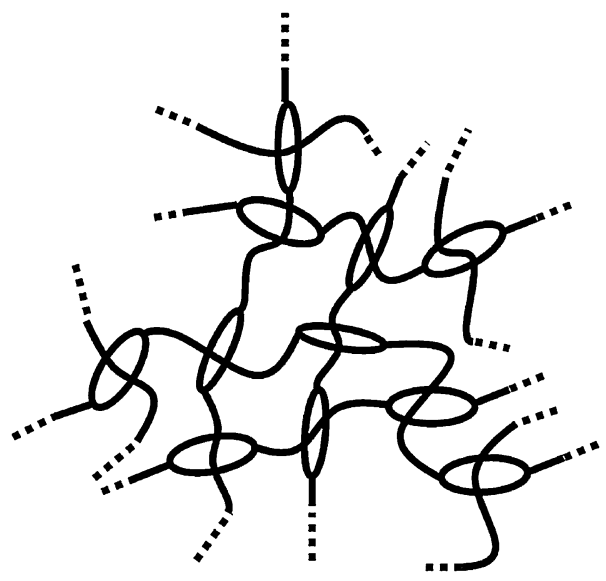

Figure 2. Non-dumbbel-shaped rotaxane gel.

column chromatography (EtOAc/MeOH $(9: 1,2: 1))$ to afford 2 (37.1 g, 95\%).

${ }^{1} \mathrm{H}$ NMR $\left(270 \mathrm{MHz}, \mathrm{CDCl}_{3}\right) \delta 5.89-5.71\left(\mathrm{~m}, 2 \mathrm{H}, \mathrm{CH}_{2}=\mathrm{CH}-\right)$, 5.03-4.88 (t, 4H, $\left.\mathrm{CH}_{2}=\mathrm{CH}-\right), 4.19-4.11\left(\mathrm{~s}, 4 \mathrm{H},-\mathrm{COOCH}_{2}-\right)$, 3.55-3.41 (s, 4H, - $\left.\mathrm{CH}_{2}-\mathrm{N}-\right), 2.35-2.23$ (t, 4H, - $\left.\mathrm{CH}_{2} \mathrm{COO}-\right)$, 2.08-1.98 (q, 4H, $\left.\mathrm{CH}_{2}=\mathrm{CH}-\mathrm{CH}_{2}-\right), 1.68-1.53$ (s, 4H, $-\mathrm{CH}_{2}-$ $\mathrm{CH}_{2} \mathrm{COO}-$ ), $1.48-1.42$ (s, 9H, -COO-C $\left.\left(\mathrm{CH}_{3}\right)_{3}\right), 1.41-1.20$ (m, $\left.2 \mathrm{OH}, \mathrm{CH}_{2}=\mathrm{CH}-\mathrm{CH}_{2}-\left(\mathrm{CH}_{2}\right)_{5}{ }^{-}\right)$. Anal. Calcd. For $\mathrm{C}_{31} \mathrm{H}_{55} \mathrm{NO}_{6}$ : C, 69.24; H, 10.31; N, 2.60. Found: C, 68.24; H, 10.66; N, 2.78. $\mathrm{N}, \mathrm{N}$-Bis(undec-10-enoyloxyethyl)ammonium Hexafluorophosphate (AXLE). To a solution of $2(3.00 \mathrm{~g}, 5.58 \mathrm{mmol})$ in chloroform $(3 \mathrm{~mL})$ was added trifluoroacetic acid $(3 \mathrm{~mL})$, followed by stirring at room temperature for $4 \mathrm{~h}$. The solution was evaporated in vacuo, and the residue was diluted with $\mathrm{CH}_{2} \mathrm{Cl}_{2}$. The organic layer was washed with saturated ammonium hexafluorophosphate aqueous solution. The organic layer was then dried over $\mathrm{MgSO}_{4}$ and evaporated to give axle component as a white solid $(2.25 \mathrm{~g}, 69 \%)$.

mp. 61-62 ${ }^{\circ} \mathrm{C} ;{ }^{1} \mathrm{H}$ NMR $\left(270 \mathrm{MHz}, \mathrm{CDCl}_{3}\right) \delta 5.89-5.71(\mathrm{~m}$, $2 \mathrm{H}, \mathrm{CH}_{2}=\mathrm{CH}-$ ), 5.03-4.88 (t, $\left.4 \mathrm{H}, \mathrm{CH}_{2}=\mathrm{CH}-\right), 4.47-4.35(\mathrm{~s}$, $4 \mathrm{H}$, -COOC $\mathrm{H}_{2}-$ ), 3.48-3.35 (s, 4H, $\left.-\mathrm{CH}_{2}-\mathrm{N}-\right), 2.48-2.39$ (t, $\left.4 \mathrm{H},-\mathrm{CH}_{2} \mathrm{COO}-\right), 2.08-1.98$ (q, $4 \mathrm{H}, \mathrm{CH}_{2}=\mathrm{CH}-\mathrm{CH}_{2}-$ ), $1.68-$ 1.51 (s, $\left.4 \mathrm{H},-\mathrm{CH}_{2}-\mathrm{CH}_{2} \mathrm{COO}-\right), 1.41-1.20\left(\mathrm{~m}, 20 \mathrm{H}, \mathrm{CH}_{2}=\mathrm{CH}\right.$ $\left.\mathrm{CH}_{2}-\left(\mathrm{CH}_{2}\right)_{5}\right)^{-}$; MALDI-TOF mass of $\mathrm{C}_{26} \mathrm{H}_{48} \mathrm{NO}_{4}{ }^{+}$Calcd.: 438.66; Found: $437.92\left(\mathrm{M}-\mathrm{PF}_{6}\right)^{+}$. Anal. Calcd. For $\mathrm{C}_{26} \mathrm{H}_{48} \mathrm{~F}_{6}$ $\mathrm{NO}_{4} \mathrm{P}: \mathrm{C}, 53.51 ; \mathrm{H}, 8.29 ; \mathrm{N}, 2.40$. Found: C, 54.31; H, 8.72; N, 2.72 .

\section{Synthesis of WHEEL}

Triethylene Glycol Monotosylate (3). To a solution of triethylene glycol $(90.6 \mathrm{~g}, 0.600 \mathrm{~mol})$, DMAP $(0.147 \mathrm{~g}, 1.21$ $\mathrm{mmol})$, triethylamine $(50.4 \mathrm{~mL}, 0.362 \mathrm{~mol})$ in THF $(120 \mathrm{~mL})$ was slowly added $p$-toluenesulfonyl choloride $(23.0 \mathrm{~g}, 0.121$ $\mathrm{mol})$ in THF $(100 \mathrm{~mL})$, and the solution was stirred at room temperature for $23 \mathrm{~h}$. The reaction mixture was filtrated, and the filtrate was concentrated. The residue was chromatographed over $\mathrm{SiO}_{2}$ using EtOAc. The aimed compound was isolated as a colorless liquid $(30.0 \mathrm{~g}, 81 \%) .{ }^{26}$

${ }^{1} \mathrm{H}$ NMR $\left(270 \mathrm{MHz}, \mathrm{CDCl}_{3}\right) \delta 7.86-7.76(\mathrm{~d}, 2 \mathrm{H}, \mathrm{Ph}), 7.43-$ 7.33 (d, 2H, Ph), 4.22-4.15 (t, 2H, Ts-OCH2-), 3.80-3.58 (m, $10 \mathrm{H}$, Ts- $\left.\mathrm{OCH}_{2}-\left(\mathrm{OCH}_{2}\right)_{4} \mathrm{CH}_{2} \mathrm{OH}\right), 2.45$ (s, 3H, $\left.\mathrm{CH}_{3}-\mathrm{Ph}\right)$.

Ethyl 3,4-Dihydroxybenzoate (4). A mixture of 3,4-dihydroxybenzoic acid $(8.0 \mathrm{~g}, 0.052 \mathrm{~mol})$ and a catalytic amount of $p$ toluenesulfonic acid $(0.49 \mathrm{~g}, 2.60 \mathrm{mmol})$ was dissolved in EtOH $(250 \mathrm{~mL})$, and refluxed for $6 \mathrm{~d}$. The solution was evaporated under reduced pressure, and the resulting concentrate was diluted with EtOAc, followed by washing with water. The organic layer was evaporated to give the product as a white crystalline solid $(8.43 \mathrm{~g}, 89 \%){ }^{26}$

${ }^{1} \mathrm{H}$ NMR $\left(270 \mathrm{MHz}, \mathrm{CDCl}_{3}\right) \delta 7.73-7.68(\mathrm{~s}, 1 \mathrm{H}, \mathrm{Ph}), 7.60$ $7.53(\mathrm{~d}, 1 \mathrm{H}, \mathrm{Ph}), 6.94-6.86(\mathrm{~d}, 1 \mathrm{H}, \mathrm{Ph}), 4.38-4.27\left(\mathrm{q}, 2 \mathrm{H}, \mathrm{CH}_{3}-\right.$ $\left.\mathrm{CH}_{2}-\right), 1.39-1.33$ (t, 3H, $\mathrm{CH}_{3}-\mathrm{CH}_{2-}$ ).

4-Ethyl-1,2-bis[2-[2-(2-hydroxyethoxy)ethoxy]ethoxy]benzoate (5). $4(8.0 \mathrm{~g}, 0.040 \mathrm{~mol})$, triethylene glycol monotosylate $(29.4 \mathrm{~g}, 0.097 \mathrm{~mol})$, and $\mathrm{K}_{2} \mathrm{CO}_{3}(15.3 \mathrm{~g}, 0.10 \mathrm{~mol})$ was dissolved in acetone $(240 \mathrm{~mL})$, and refluxed for $17 \mathrm{~h}$. The solution was filtrated, and the filtrate was concentrated. Column chromatography $\left(\mathrm{SiO}_{2}\right)$ with $\mathrm{MeOH} /$ EtOAc (1:9) yielded a yellowish viscous oil $(15.0 \mathrm{~g}, 76 \%) .{ }^{1} \mathrm{H}$ NMR $(270 \mathrm{MHz}$, $\left.\mathrm{CDCl}_{3}\right) \delta$ 7.73-7.65 (d, 1H, Ph), 7.63-7.58 (s, 1H, Ph), 6.94$6.86(\mathrm{~d}, 1 \mathrm{H}, \mathrm{Ph}), 4.39-4.30\left(\mathrm{q}, 2 \mathrm{H}, \mathrm{CH}_{3}-\mathrm{CH}_{2}-\right), 4.20-4.15$ (t, 4H, Ph- $\left.\mathrm{OCH}_{2}-\right), 3.95-3.60\left(\mathrm{~m}, 20 \mathrm{H}, \mathrm{Ph}-\mathrm{OCH}_{2}-\left(\mathrm{OCH}_{2}\right)_{4}-\right.$ $\mathrm{CH}_{2} \mathrm{OH}$ ), 1.39-1.33 (t, $3 \mathrm{H}, \mathrm{CH}_{3}-\mathrm{CH}_{2}-$ ).

4-Ethyl-1,2-bis[2-[2-[2-[(4-toluene)sulfonyl]oxy]ethoxy]ethoxy]ethoxy]benzoate (6). To a solution of diol 5 (15.0 g, 33.6 mmol), DMAP $(0.082 \mathrm{~g}, 0.67 \mathrm{mmol})$, triethylamine $(14.1 \mathrm{~mL}$, $100.0 \mathrm{mmol})$ in THF $(80 \mathrm{~mL})$ was slowly added a solution of $p$ toluenesulfonyl chloride $(19.2 \mathrm{~g}, 100.0 \mathrm{mmol})$ in THF $(50 \mathrm{~mL})$, and the solution was stirred at room temperature for $165 \mathrm{~h}$. The reaction mixture was filtrated and the filtrate was concentrated. The residue was purified by $\mathrm{SiO}_{2}$ column chromatography ( $n$ - 
hexane/EtOAc (1:1), EtOAc) to afford ditosylate $\mathbf{6}$ as yellowish viscous oil $(22.6 \mathrm{~g}, 89 \%) .{ }^{1} \mathrm{H} \mathrm{NMR}\left(270 \mathrm{MHz}, \mathrm{CDCl}_{3}\right) \delta$ 7.86-7.76 (d, 4H, Ph (Ts)), 7.73-7.65 (d, 1H, Ph), 7.60-7.55 (s, $1 \mathrm{H}, \mathrm{Ph}), 7.38-7.32$ (d, 4H, Ph (Ts)), 6.92-6.86 (d, 1H, Ph), 4.39-4.30 (q, 2H, $\mathrm{CH}_{3}-\mathrm{CH}_{2}-$ ), 4.25-4.15 (t, 4H, Ph-OCH $2^{-}$), 3.88-3.59 (m, 20H, Ph-OCH $\left.-\left(\mathrm{OCH}_{2}\right)_{4} \mathrm{CH}_{2} \mathrm{OH}\right), 2.40$ (s, 6H, $\mathrm{CH}_{3}-\mathrm{Ph}$ ), 1.41-1.33 (t, 3H, $\mathrm{CH}_{3}-\mathrm{CH}_{2}-$ ). Anal. Calcd. For $\mathrm{C}_{35} \mathrm{H}_{46} \mathrm{O}_{14} \mathrm{~S}_{2}$ : C, 55.69; H, 6.14. Found: C, 56.66; H, 6.39.

Bis(ethoxycarbonylbenzo)-24-crown-8 Ether (7). A suspension of $6(7.5 \mathrm{~g}, 9.9 \mathrm{mmol})$ and cesium carbonate $(16.1 \mathrm{~g}, 49.5$ $\mathrm{mmol})$ in acetonitrile $(400 \mathrm{~mL})$ was stirred at $60^{\circ} \mathrm{C}$ for $30 \mathrm{~min}$. Then, a solution of $4(1.61 \mathrm{~g}, 8.91 \mathrm{mmol})$ in THF $(100 \mathrm{~mL})$ was added dropwise. The mixture was heated under reflux for $100 \mathrm{~h}$. The suspension was filtrated, and the filtrate was evaporated under reduced pressure. The resulting residue was diluted with water and extracted with dichloromethane, followed by drying over magnesium sulfate. Upon removal of the solvent, the residue was purified by column chromatography $\left(\mathrm{SiO}_{2}, \mathrm{CH}_{2} \mathrm{Cl}_{2} / \mathrm{MeOH}(3: 1,1: 1)\right)$ to produce the compound 7 as a white solid $(2.99 \mathrm{~g}, 57 \%)$.

${ }^{1} \mathrm{H}$ NMR $\left(270 \mathrm{MHz}, \mathrm{CDCl}_{3}\right) \delta 7.70-7.61(\mathrm{~d}, 2 \mathrm{H}, \mathrm{Ph}), 7.58-$ 7.53 (s, 2H, Ph), 6.90-6.83 (d, 2H, Ph), 4.39-4.28 (q, 4H, $\mathrm{CH}_{3}-$ $\mathrm{CH}_{2-}$ ), 4.25-4.15 (t, 8H, Ph-OCH $\left.2^{-}\right), 4.23-3.65$ (m, $16 \mathrm{H}$, $-\mathrm{CH}_{2} \mathrm{CH}_{2} \mathrm{O}-$ ), $1.41-1.33$ (q, 6H, $\mathrm{CH}_{3}-\mathrm{CH}_{2}-$ ). Anal. Calcd. For $\mathrm{C}_{30} \mathrm{H}_{40} \mathrm{O}_{12}$ : C, 60.80; H, 6.80. Found: C, 60.23; H, 6.69.

Bis(hydoxymethylbenzo)-24-crown-8 Ether (8). To a suspension of $\mathrm{LiAlH}_{4}(2.25 \mathrm{~g}, 59.3 \mathrm{mmol})$ in THF was carefully added a solution of $7(2.93 \mathrm{~g}, 4.94 \mathrm{mmol})$ in $\mathrm{THF}$, and the mixture was refluxed for $60 \mathrm{~h}$. Upon cooling to room temperature, a saturated aqueous solution of $\mathrm{NaHCO}_{3}$ was added to the solution. The solution was filtrated, and the filtrate was extracted with dichloromethane. The organic layer was dried over anhydrous $\mathrm{MgSO}_{4}$ and evaporated under reduced pressure to give $\mathbf{8}$ as a white solid $(2.47 \mathrm{~g}, 98 \%)$. 8 was used in next reaction without further purification. ${ }^{27}$

${ }^{1} \mathrm{H}$ NMR $\left(270 \mathrm{MHz}, \mathrm{CDCl}_{3}\right) \delta 6.95-6.80(\mathrm{~m}, 6 \mathrm{H}, \mathrm{Ph}), 4.62-$ 4.48 (s, 4H, Ph-CH2-OH), 4.21-3.65 (m, 24H, - $\mathrm{CH}_{2} \mathrm{CH}_{2} \mathrm{O}-$ ).

Bis(undec-10-enoyloxymetylbenzo)-24-crown-8 Ether (WHEEL). 8 (2.46 g, $4.84 \mathrm{mmol}$ ) was dissolved in THF, and triethylamine $(2.70 \mathrm{~mL}, 19.4 \mathrm{mmol})$ was added to the solution. To the solution was added dropwise a solution of 10-undecenoyl chloride ( $3.30 \mathrm{~g}, 16.3 \mathrm{mmol})$ in THF. The mixture was stirred at room temperature for $48 \mathrm{~h}$. After the stirring, a saturated aqueous solution of $\mathrm{NaHCO}_{3}$ was poured in the reaction mixture, followed by extraction with dichloromethane. The organic layer was dried over anhydrous $\mathrm{MgSO}_{4}$ and evaporated under reduced pressure to give a residue as yellow oil. The residue was purified he residue was purified by column chromatography $\left(\mathrm{SiO}_{2}\right.$, $\mathrm{CH}_{2} \mathrm{Cl}_{2} /$ EtOAc $(5: 1,1: 1)$ ). The column choromatography yielded the wheel as a white solid $(2.78 \mathrm{~g}, 68 \%) .{ }^{1} \mathrm{H}$ NMR $\left(270 \mathrm{MHz}, \mathrm{CDCl}_{3}\right) \delta$ 6.94-6.82 (m, 6H, Ph), 5.90-5.73 (m, 2H, $\left.\mathrm{CH}_{2}=\mathrm{CH}-\right)$, 5.05-4.95 (m, 8H, $\left.\mathrm{CH}_{2}=\mathrm{CH}-, \mathrm{Ph}-\mathrm{CH}_{2}-\mathrm{O}-\mathrm{CO}-\right)$, 4.18-3.79 (m, 24H, - $\left.\mathrm{CH}_{2} \mathrm{CH}_{2} \mathrm{O}-\right), 2.38-2.28\left(\mathrm{~m}, 4 \mathrm{H},-\mathrm{CH}_{2}-\right.$ COO-), 2.10-1.96 (m, 4H, $\left.\mathrm{CH}_{2}=\mathrm{CH}-\mathrm{CH}_{2}-\right), 1.70-1.58$ (m, 4H, - $\mathrm{CH}_{2} \mathrm{CH}_{2}$-COO-), 1.43-1.19 (m, 20H, $\left.\mathrm{CH}_{2}=\mathrm{CH}-\mathrm{CH}_{2}-\left(\mathrm{CH}_{2}\right)_{5}-\right)$; MALDI-TOF mass of $\mathrm{C}_{48} \mathrm{H}_{72} \mathrm{O}_{12} \mathrm{Na}^{+}$Calcd.: 864.07; Found:
$862.50(\mathrm{M}+\mathrm{Na})^{+}$. Anal. Calcd. For $\mathrm{C}_{48} \mathrm{H}_{72} \mathrm{O}_{12}: \mathrm{C}, 68.54 ; \mathrm{H}$, 8.63. Found: C, 68.24; H, 10.66 .

\section{Metathesis Reaction of AXLE and WHEEL Mixture}

To a solution of AXLE $(0.05 \mathrm{~g}, 0.086 \mathrm{mmol})$ and WHEEL $(0.073 \mathrm{~g}, 0.086 \mathrm{mmol})$ in dichlorometane $(0.5 \mathrm{~mL})$ was added a ruthenium carbene complex $9(7.1 \mathrm{mg}, 0.0086 \mathrm{mmol})$, and the mixture was stirred at $40^{\circ} \mathrm{C}$ for $24 \mathrm{~h}$. The reaction was stopped by adding ethyl vinyl ether. The resulting gel compound was wash with dichlorometane and DMF several times, followed by drying to give elastomer as a purple solid (recover rate: $85 \%)$.

\section{RESULTS AND DISCUSSION}

The used AXLE and the used WHEEL were prepared as shown in Schemes 1 and 2. AXLE was synthesized from diethanolamine in 3 steps. WHEEL was synthesized from triethylene glycohol in 6 steps. The axle component and the wheel component have two double bonds as a common functional group. As a result, the random metathesis reaction of these double bonds between pseudorotaxanes gives a stable rotaxane gel, which holds axles in wheels by end-capping with other wheels such as shown in Figure 2.

Rotaxane gel was synthesized with the axle, the wheel, and the ruthenium carbene complex $\mathbf{9},{ }^{28-32}$ as shown in Scheme 3. First, the mixed solution of AXLE and WHEEL in $\mathrm{CH}_{2} \mathrm{Cl}_{2}$ was prepared to give a pseudorotaxane (AXLE/WHEEL complex) in the solution. And then, the catalyst $\mathbf{9}$ was added to the mixture solution in order that four olefins of a pseudorotaxane (four-arms-pseudorotaxane) react with olefins of other pseudorotaxans at random. The resulting purple solution was refluxed to give a gel-like solid. The product was washed with DMF and $\mathrm{CH}_{2} \mathrm{Cl}_{2}$, followed by drying in vacuo to afford a purple-red resin as a final product. We tried to purify the gel by washing with various solvents such as DMF and DMSO, but the purple color was not removed from the gel.

The product showed insolubility and swelling in various organic solvents, and the results of solubility and swelling are listed in Table I. The obtained polymer showed insolubility in all solvent, and tended to increase swelling ability for chloroform, dichloromethane, and aprotic solvents such as $\mathrm{N}, \mathrm{N}$ dimethylformamide (DMF), acetone, and acetonitrile. On the other hand, the polymer showed poor swelling ability for $n$ hexane, diethyl ether, and protic solvents such as methanol and ethanol.

Figure 3 represented photographs of the product before and after swelling in dichloromethane. Although the dry product before swelling was a solid resin, the product after swelling in $\mathrm{CH}_{2} \mathrm{Cl}_{2}$ became a transparent gel. In addition, the resulting gel held solvent, though the glass vial of gel was turned upside down.

To confirm the formation of network structure by metathesis reaction of four-arms-pseudorotaxane, the gelation process was followed by ${ }^{1} \mathrm{H}$ NMR spectra (Figure 4). The gelation was carried out by heating of a NMR tube that mixed AXLE 

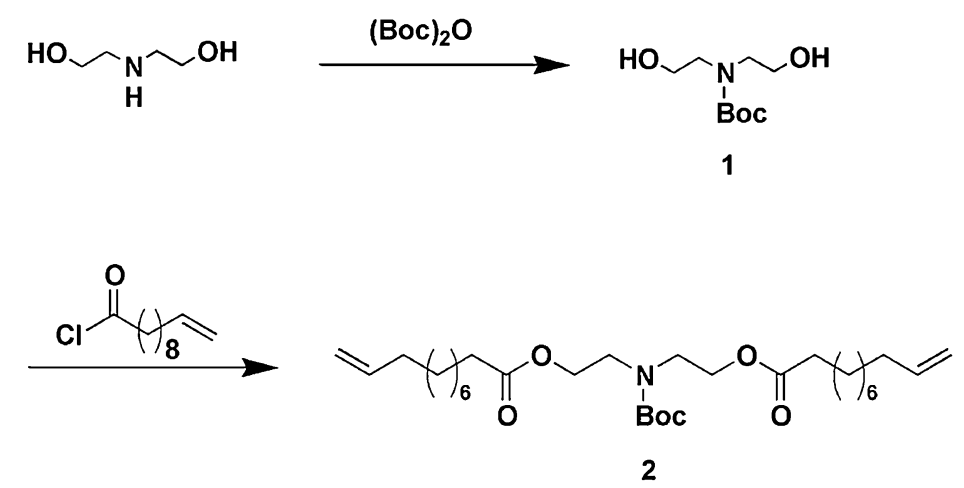

(1)TFA
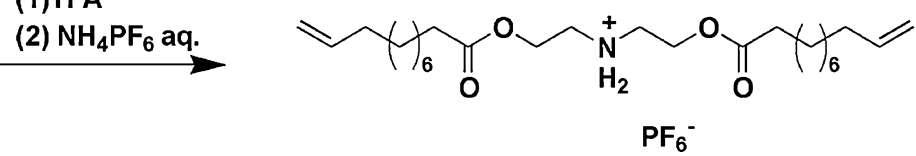

AXLE

Scheme 1. Synthesis of AXLE.

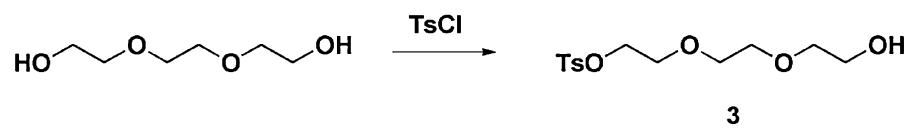<smiles>CCOC(=O)c1ccc(O)c(O)c1</smiles>

4

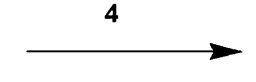<smiles>CCOC(=O)c1ccc(OCCOCCOCCO)c(OCCOCCO)c1</smiles>

5

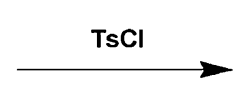<smiles>CCOC(=O)c1ccc(OCCOCCOCCO[S+](F)(F)F)c(OCCOCCOCCO[S+](F)(F)F)c1</smiles>

6
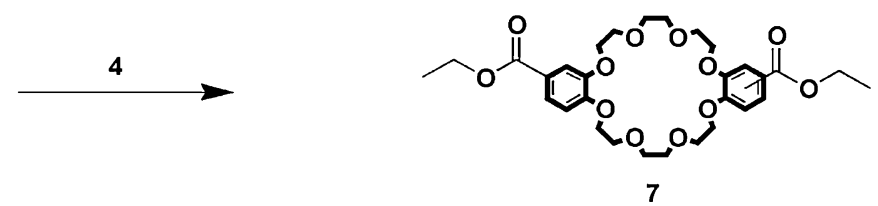

(1) $\mathrm{LiAlH}_{4}$

(2) Undecenoyl Chloride

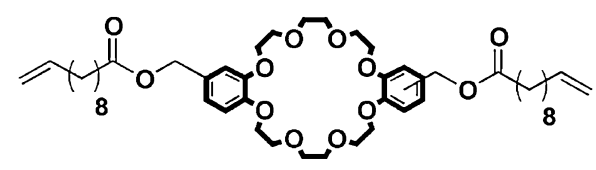

WHEEL

Scheme 2. Synthesis of WHEEL.

(0.12 mol/L), WHEEL $(0.12 \mathrm{~mol} / \mathrm{L})$, and catalyst $9(0.012$ $\mathrm{mol} / \mathrm{L})$ in $\mathrm{CD}_{2} \mathrm{Cl}_{2}$.

Before the addition of catalyst 9 , the spectrum of the mixture was different from the superimposed spectrum of AXLE and
WHEEL, and showed the formation of about 95 percent of pseudorotaxane in the system, based on the shift changes of methylene protons $H_{a}$ and $H_{b}(4.35 \mathrm{ppm}$ and $3.75 \mathrm{ppm})$ adjacent to ammonium salt units of AXLE (Figure 4(A)). 


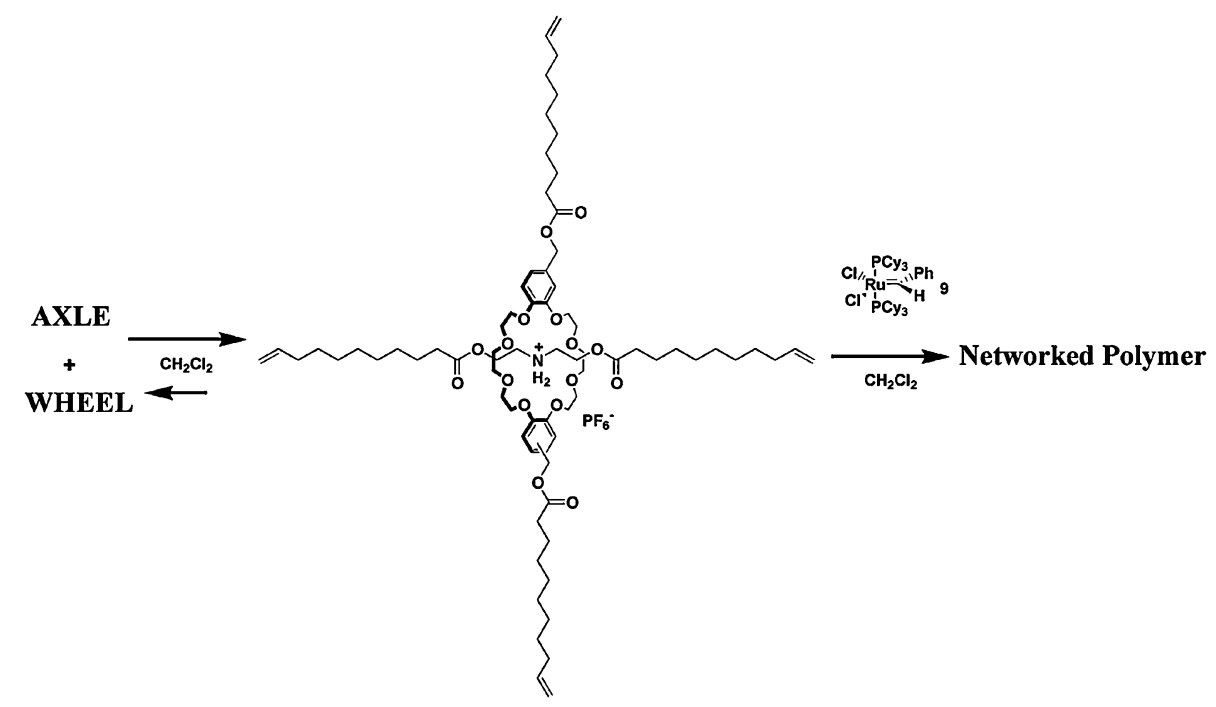

Four-arms-pseudorotaxane

Scheme 3. Synthesis of rotaxane gel.

Table I. Swelling Properties of Product

\begin{tabular}{ccc}
\hline Solvent & Solubility Test & $\begin{array}{c}\text { Percentage Swelling } \\
{[\%]}\end{array}$ \\
\hline chloroform & $\left.\right|^{\mathrm{a}}$ & 770 \\
dichloromethane & $\mathrm{I}$ & 790 \\
acetone & $\mathrm{I}$ & 390 \\
acetonitrile & $\mathrm{I}$ & 320 \\
$N, N$-dimethylformamide & $\mathrm{I}$ & 1220 \\
benzene & $\mathrm{I}$ & 370 \\
toluene & $\mathrm{I}$ & 260 \\
tetrahydrofuran & $\mathrm{I}$ & 490 \\
ethyl acetate & $\mathrm{I}$ & 320 \\
$n$-hexane & $\mathrm{I}$ & 50 \\
diethyl ether & $\mathrm{I}$ & 50 \\
methanol & $\mathrm{I}$ & 60 \\
ethanol & $\mathrm{I}$ & 80 \\
\hline
\end{tabular}

${ }^{a}$ Insoluble. ${ }^{b}$ percentage swelling $=(([$ weigh of swelled gel $]-$ [weight of dried gel])/[weight of dried gel]) $\times 100$.

After the addition of catalyst 9, two signal (a) and (b) attributable to terminal olefin of four-arms-pseudorotaxane made less in size, and a new signal (c) attributable to internal olefins appeared in the spectrum of four-arms-pseudorotaxane (Figure 4(B)). The signal intensity of internal olefin increased as time advances, and the solution gelated after $25 \mathrm{~h}$; in fact, the ratio of the formation of internal olefins was calculated to be $c a$. $60 \%$ by using ${ }^{1} \mathrm{H}$ NMR spectrum, and ultimately, the ratio reached $c a$. $85 \%$ after $95 \mathrm{~h}$. On the other hand, the metathesis reaction between compound 2 and WHEEL quantitatively proceeded, but the resulting solution showed no gelation $\left(M_{\mathrm{n}}\right.$ of the product $\left.=7,000\right)$.

These results indicate that that the metathesis reaction of the four-arms-pseudorotaxane consisting of AXLE and WHEEL was essential for the formation of the desired network polymer, and WHEEL played two important roles to make up the (a)

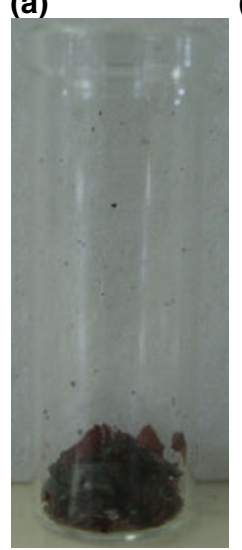

(b)

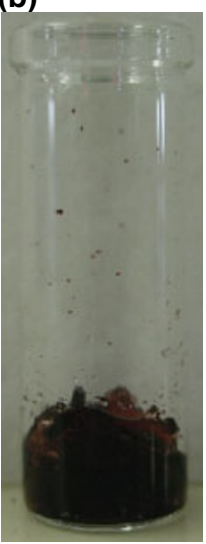

(c)

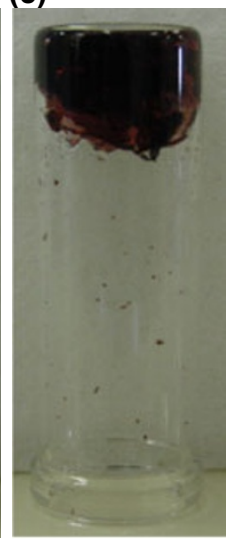

Figure 3. Photographs of the product (a) before swelling, (b) after swelling in $\mathrm{CH}_{2} \mathrm{Cl}_{2}$, and (c) the inverted glass vial of (b).

rotaxane network structure in the system; inclusion of axle, and protection of other crownethers against dethreading (Figure 5).

\section{CONCLUSION}

In conclusion, we have succeeded in synthesizing a new interlocked gel consisting of only two components by metathesis reaction. The resulting polyrotaxane was insoluble and selectively swelled in various organic solvents. Further works on application and structure are currently in progress.

Received: October 10, 2007

Accepted: November 20, 2007

Published: January 10, 2008 


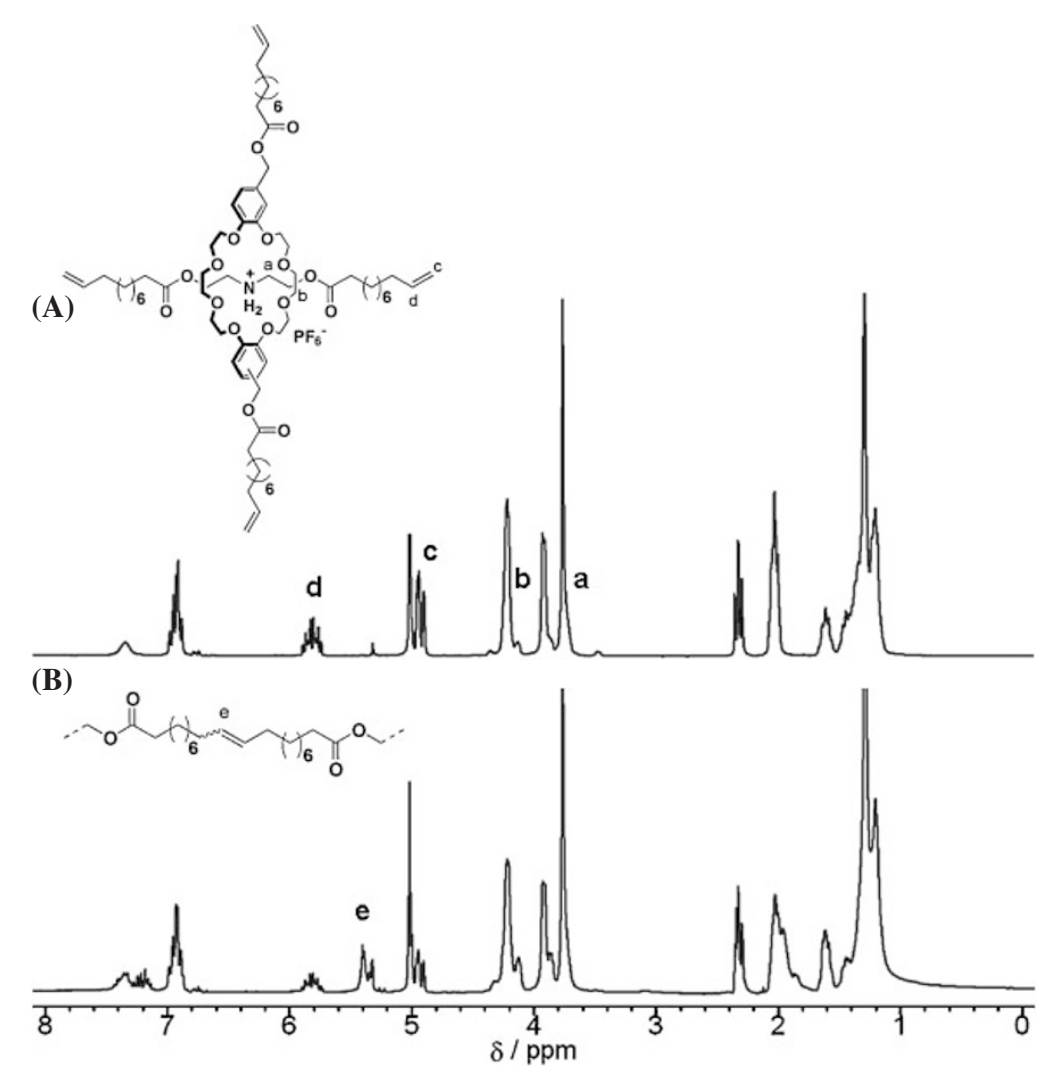

Figure 4. ${ }^{1} \mathrm{H}$ NMR spectral changes during the gelation $\left(270 \mathrm{MHz}, \mathrm{CD}_{2} \mathrm{Cl}_{2}\right)$. (A) Before adding Grubbs 1st, and (B) $25 \mathrm{~h}$ after adding Grubbs 1 st. The initial concentrations of the axle and the wheel were $0.12 \mathrm{~mol} / \mathrm{L}$.

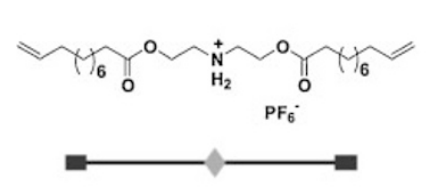

AXLE

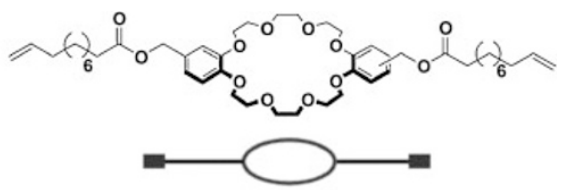

WHEEL

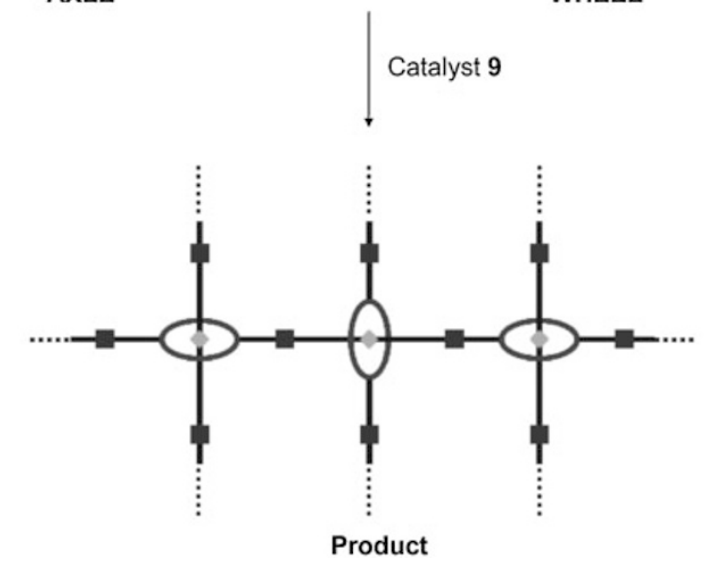

Figure 5. Proposed partial structure of networked polymer.

\section{REFERENCES}

1. A. Harada, J. Li, and M. Kamachi, Nature, 364, 516 (1993).

2. A. Harada, J. Li, and M. Kamachi, Nature, 370, 126 (1994).

3. Y. X. Shen, D. Xie, and H. W. Gibson, J. Am. Chem. Soc., 116, 537 (1994).
4. C. Fischer, M. Nieger, O. Mogck, V. Böhmer, R. Ungaro, and F. Vögtle, Eur. J. Org. Chem., 1, 155 (1998).

5. P. R. Ashton, M. C. T. Fyfe, J. F. Stoddart, A. J. P. White, and D. J. Williams, Tetrahedron Lett., 39, 5455 (1998).

6. A. M. Elizarov, S. Chiu, and J. F. Stoddart, J. Org. Chem., 67, 9175 (2002). 
7. I. Smukste, B. E. House, and D. B. Smithrud, J. Org. Chem., 68, 2559 (2003).

8. T. J. Kidd, T. J. A. Loontjens, D. A. Leigh, and J. K. Y. Wong, Angew. Chem., Int. Ed., 42, 3379 (2003).

9. H. Sasabe, N. Kihara, Y. Furusho, K. Mizuno, A. Ogawa, and T. Takata, Org. Lett., 6, 3957 (2004).

10. M. Miyauchi, T. Hoshino, H. Yamaguchi, S. Kamitori, and A. Harada, J. Am. Chem. Soc., 127, 2034 (2005).

11. Y. Tachibana, H. Kawasaki, N. Kihara, and T. Takata, J. Org. Chem., 71, 5093 (2006).

12. Y. Okumura and K. Ito, Adv. Mater., 13, 485 (2001).

13. T. Oku, Y. Furusho, and T. Takata, Angew. Chem., Int. Ed., 43, 966 (2004).

14. J. S. Hannam, T. J. Kidd, D. A. Leigh, and A. J. Wilson, Org. Lett., 5, 1907 (2003).

15. J. A. Wisner, P. D. Beer, M. G. B. Drew, and M. R. Sambrook, J. Am. Chem. Soc., 124, 12469 (2002).

16. R. G. E. Coumans, J. A. A. Elemans, P. Thordarson, R. J. M. Nolte, and A. E. Rowan, Angew. Chem., Int. Ed., 42, 650 (2003).

17. E. N. Guidry, S. J. Cantrill, J. F. Stoddart, and R. H. Grubbs, Org. Lett., 7, 2129 (2005).

18. A. F. M. Kilbinger, S. J. Cantrill, A. W. Waltman, M. W. Day, and R. H. Grubbs, Angew. Chem., Int. Ed., 42, 3281 (2003).

19. H. Iwamoto, K. Itoh, H. Nagamiya, and Y. Fukazawa, Tetahedron
Lett., 44, 5773 (2003).

20. X. Zhu and C. Chen, J. Am. Chem. Soc., 127, 13158 (2005).

21. C. Gong and H. W. Gibson, J. Am. Chem. Soc., 119, 5862 (1997).

22. C. Gong and H. W. Gibson, J. Am. Chem. Soc., 119, 8585 (1997).

23. H. W. Gibson, D. S. Nagvekar, N. Yamaguchi, S. Bhattacharjee, H. Wang, M. J. Vergne, and D. M. Hercules, Macromolecules, 37, 7514 (2004).

24. H. W. Gibson, Z. Ge, F. Huang, J. W. Jones, H. Lefebvre, M. J. Vergne, and D. M. Hercules, Macromolecules, 38, 2626 (2005).

25. J. M. Orban, T. M. Chapman, W. R. Wagner, and R. Jankowski, J. Polym. Sci., Part A: Polym. Chem., 37, 3441 (1999).

26. D. J. Feng, X. Q. Li, X. Z. Wang, X. K. Jiang, and Z. T. Li, Tetrahedron, 60, 6137 (2004).

27. Y. Kohsaka, G. Konishi, and T. Takata, Polym. J., 39, 861 (2007).

28. E. L. Dias, S. T. Nguyen, and R. H. Grubbs, J. Am. Chem. Soc., 119, 3887 (1997).

29. R. H. Grubbs and S. Chang, Tetrahedron, 54, 4413 (1998).

30. W. Buchowicz and J. C. Mol, J. Mol. Catal. A: Chem., 148, 97 (1999).

31. M. S. Sanford, M. Ulman, and R. H. Grubbs, J. Am. Chem. Soc., 123, 749 (2001).

32. M. S. Sanford, J. A. Love, and R. H. Grubbs, J. Am. Chem. Soc., 123, 6543 (2001). 